\title{
The Propensity to Patent Digital Technology: Mirroring Digitalization Processes in Germany with Intellectual Property in a European Perspective
}

\section{Andreas Bielig ${ }^{1}$}

Received: 21 June 2021 / Accepted: 1 February 2022

(c) The Author(s), under exclusive licence to Springer Science+Business Media, LLC, part of Springer Nature 2022

\begin{abstract}
Digitalization processes are main drivers of innovation activities, so promoting digital technology is priority of economic and industrial policy. Examining digital technology patent surge, the article analyzes German innovation positions in digital technology filings at European Patent Office in 2010-2019. Germany belongs to largest originations with computer technology as major field. Compared with USA and China, it finds in second innovation league and loses ground. Chinese strengths derive from specialization advantages in digital technologies. However, analysis of entire digital technology filings at EPO reveals no evidence for innovation advantages of increased specializations in European perspective.
\end{abstract}

Keywords Digital technology · Innovation · Patents · Competitiveness · Specialization · Germany

JEL Classification $\mathrm{O} 31 \cdot \mathrm{O} 33 \cdot \mathrm{O} 34$

\section{Introduction}

Since many decades, the use of digital technology increasingly forms individual patterns and economic action in our societies (Schallmo \& Williams, 2018). In a general perspective, digital technologies can be defined as electronic tools, automatic systems, technological devices, or resources based on computational hardware, software, and network solutions for generating, processing, or storing of information by using bits as smallest information units in a binary system of zero and one (Johnson, 2021; Gabler Wirtschaftslexikon, 2022). Digitalization processes trigger radical changes in growing numbers of

Andreas Bielig

abielig@sgh.waw.pl

1 Warsaw School of Economics, Department of German Economy Research, World Economy Research Institute, ul. Rakowiecka 24, 02-521 Warsaw, Poland 
markets, industrial sectors, national economies, and international exchange (World Economic Forum, 2018, pp. 6-8). They restructure production, organization, and innovation processes of enterprises but reshape also cooperation and competition relations on markets (Lobo \& White, 2017; Pershina et al., 2019; Verstegen et al., 2019; Cirillo et al., 2020; Balsmeier \& Woerter, 2019, Eiteneyer et al., 2019; Nambisan et al., 2019; Domini et al., 2020; Scott et al., 2017). Digital technologies often function as enablers by lowering barriers for market entry. With the emergence of digital newcomers, traditional incumbents are challenged in new technology areas with a reset of the competition field (Brunswicker \& Schecter, 2019; Forman \& Zeebroeck, 2019; Helfat \& Raubitschek, 2018; Beltagui et al., 2020; Teece, 2018; Kim et al., 2017). Hence, promotion of digitalization by economic policy becomes popular in industrialized economies. This reflects the public discourse by keywords ranging between resplendent buzzwords and ambitious political programs, like for Germany Industry 4.0 (Acatech, 2013, pp. 18-26), Digital Economy (European Commission, 2020, pp. 3f), or Digital Transformation (Bundesregierung, 2020, pp. 8 f). Until recent years, Germany lagged behind the digital transformation forefront, sticking to its core competences in manufacturing and ignoring future economic potential of digital technologies (The Economist, 2015, OECD, 2018, Bitkom, 2020). To evaluate the current economic progress of German digital transformation, a comparative empirical analysis at international competition level is required. To address major German achievements in the European Common Market, the analysis focus is on European perspective. This contribution tries an answer on three research questions: (1) Which development digital technology filings experienced in 2010-2019 in a European perspective? (2) Which competitive position has Germany in digital technologies and what are observable major trends? (3) Are there empirical signs for specialization advantages in European patenting of digital technologies? As data basis, I use patent applications for digital technologies filed at the European Patent Office (EPO) as an indicator of digital advancement of filing institutions. For international comparisons of German digital technology competencies, also the German Patent and Trademark Office (DPMA) (DPMA, 2021) or, for major foreign markets, the US (USPTO) (USPTO, 2020) and the Japan Patent Office (JPO) (JPO, 2021) as well as the China National Intellectual Property Administration (CNIPA) (CNIPA, 2021) provide filing data at national level. The European analysis focus is based on two major aspects: first, the considerable importance of the Common Market for German applicants and, second, the empirical evidence for home biases of domestic patenting entities (Bacchiocchi \& Montobbio, 2010; Criscuolo, 2006). Hence, patent analysis at European level provides valuable insights into technological advancement of the German economy in digital technologies and ensures a suitable framework for measuring the economy's position in the international competition at an important supranational market. Today, dominant shares of digital technologies and product elements are protected by intellectual property rights, especially by patents. Patent protection is often, beside other competition options, like time lead, non-disclosure, or strategic bundling with complementary assets, regarded as suitable instrument to appropriate revenues of new innovative solutions, but also used for strategic patenting, resulting, e.g., in patent fencing or patent thickets (Cohen et al., 2000; Frietsch et al., 2010; Weber et al., 2007). However, digital product and technology protection by patents is rarely analyzed with focus on macroeconomic empirical development. Chabchoub and Niosi (2005) analyze propensities to patent computer software at micro level for US and Canadian firms, Olsson and McQueen (2000) for European small- and 
medium-sized enterprises SME. Current macro analysis is provided by World Intellectual Property Organization (WIPO) IP reports or digital sector analyses published by OECD or WIPO (WIPO, 2019a; WIPO, 2019b; Zehtabchi, 2019; Hoeren et al., 2015; Baruffaldi et al., 2020). In some analyses, role of patents in fostering innovations in information and communication technologies is regarded as problematic. Current growth developments can be challenged by negative competition and innovation effects of strategic patenting in complex technology environments and lower patent quality caused by the surge of software patents (Comino et al., 2018, pp. 406f). Empirical analyses indicate an intensive use of formal protection instruments for appropriation purposes by large enterprises in digital technology, like patents, trademarks, and copyrights, whereas small businesses prefer informal instruments to protect digital assets, like lead-time advantage or rapid innovation cycles (Miric et al., 2019). However, the worldwide surge of digital technology patenting indicates increasing firm interests in protection of intangible dig tech assets for business (WIPO, 2019a). Also, European largest patent applications origination, Germany, strengthens efforts to participate in and secure potentials of future innovation and growth (EPO, 2020a). However, no empirical evidence is found for the German international innovation position in digital patents. The article aims to close this gap partially with respect to an empirical analysis on European level, focusing German international position in digital technology development and progress made during last years. Furthermore, the contribution compares German-originated patent filings of enterprises, institutions, or private persons with internationally leading economies and indicates patent specialization patterns on digital technologies. Finally, it examines whether national specializations improve the competitive position in digitalization technologies.

\section{Data and Methods}

A comprehensive dataset is used for analysis, covering entire direct applications for European patents filed at the EPO including international (PCT) applications entering the European phase in the reporting period from 2010 to 2019 (EPO, 2020b). Data categorization follows WIPO IPC technology concordance IPC8 (WIPO, 2009; WIPO, 2019c; Schmoch, 2008). IPC8 does not provide a sole field of digital technologies. Hence, for measurement of Germany's international position in digital technologies, I focus on patent applications in the following fields: (1) digital communication (H04L), (2) computer technology as the largest application field (G06\# not G06Q, G11C, G10L), with electrical digital processing (C06F) as core area, including specific digital applications like 3D printing or others, and (3) IT methods for management (G06Q). Following Schmoch (2008, p. 8), these fields cover applications for digital technology at the EPO according above definition with minor exceptions; e.g., micro-structural technology (B81) belongs due to its small quantitative relevance to semiconductors. The dataset provides filing data for 46 largest origination economies and for remaining originations at aggregated level. The reader is organized as follows: First, overall EPO digital technology patent applications in 2010-2019 are analyzed, followed second by German filings. Third, German patent position is analyzed in the European perspective. Here, descriptive statistical analysis methods are applied. Fourth, impacts of national specializations on digital technologies on patent outcomes are analyzed 
by testing a positive impact hypothesis of digital specializations on patent activities at EPO for filings of entire economies between 2010 and 2019. For this purpose, I analyze with simple OLS regression the relationship between patent specialization and patent applications of all digital technology fields. It aims to examine the hypothesis $(H)$ that increasing specialization in a technology field of digital technology influences patent activity in this field positively (see Eq. (1)). For patent outcome estimation, a dependent variable transformation with natural logarithm $\ln$ is applied.

$$
\ln P A_{j, l}^{t}=f\left(P S_{j, l}^{t}\right)
$$

with $t=1,2 \ldots 4, j=1,2 \ldots 10, l=1,2 \ldots 47$

$\mathrm{H}$ : An increasing specialization PS in a technology field t of digital technology influences patent activity PA in this field in period $j$ for economies $l$ positively.

$\mathrm{H}_{0}$ : The tested zero hypothesis $\left(\mathrm{H}_{0}\right)$ assumes that increasing specialization in a digital technology field does not influence field's patent activity in the analyzed period for analyzed economies positively.

$\mathrm{H}_{1}$ : The alternative hypothesis $\left(\mathrm{H}_{1}\right)$ assumes that increasing specializations in a digital technology field influences field's patent activity in the analyzed period for analyzed economies positively.

Patent specialization PS of an economy $l$ in a technology field $t$ in year $j$ is according to Eq. (2) defined as share of patent applications in $t$ on aggregated national applications filed in all technology fields $k$ :

$$
P S_{j, l}^{t}=\frac{P A_{j, l}^{t}}{\sum_{k=1}^{m} P A_{j, l}^{k}} \text { with } t=1,2 \ldots 4, j=1,2 \ldots 10, l=1,2 \ldots 47, k=1, \ldots m
$$

For analysis, I focus constellations of at least one digital technology patent, so data are corrected for zero count entries. The OLS regression for hypothesis verification with applications from origination economies $l$ in period $j=1 \ldots 10$ is outlined in Eq. (3). Function (4) estimates impacts of digital technology specialization in $t$ on patent activities of filing economies. Finally, with Eqs. (5), (6), (7), and (8), influences of observed specialization intensities on patent activities are analyzed for each technology field (DT-digital technology, DC-digital communication, CT-computer technology, and ITM-IT methods for management).

OLS model:

$$
\begin{gathered}
Y_{j, l}=b_{0}+b_{1} x_{j, l} \text { with } j=1,2 \ldots 10, l=1,2 \ldots 47 \\
Y_{j, l}^{P A^{t}}=b_{0}^{t}+b_{1}^{t} P S_{j, l}^{t} \text { with } t=1,2 \ldots 4, j=1,2 \ldots 10, l=1,2 \ldots 47 \\
Y_{\mathrm{j}, 1}^{\mathrm{PA}}=b_{0}^{\mathrm{DT}}+\mathrm{b}_{1}^{\mathrm{DT}} \mathrm{PS}_{\mathrm{j}, 1}^{\mathrm{DT}} \text { with } j=1,2 \ldots 10, l=1,2 \ldots 4 \\
Y_{\mathrm{j}, 1}^{\mathrm{PA}^{\mathrm{DC}}}=\mathrm{b}_{0}^{\mathrm{DC}}+\mathrm{b}_{1}^{\mathrm{DC}} \mathrm{PS}_{\mathrm{j}, 1}^{\mathrm{DC}} \text { with } j=1,2 \ldots 10, l=1,2 \ldots 4
\end{gathered}
$$




$$
\begin{gathered}
Y_{\mathrm{j}, 1}^{\mathrm{PA}}=\mathrm{b}_{0}^{\mathrm{CT}}+\mathrm{b}_{1}^{\mathrm{CT}} \mathrm{PS}_{\mathrm{j}, 1}^{\mathrm{CT}} \text { with } j=1,2 \ldots 10, l=1,2 \ldots 4 \\
Y_{\mathrm{j}, 1}^{\mathrm{PA}}=\mathrm{b}_{0}^{\mathrm{ITM}}+\mathrm{b}_{1}^{\mathrm{ITM}} \mathrm{PS}_{\mathrm{j}, 1}^{\mathrm{ITM}} \text { with } j=1,2 \ldots 10, l=1,2 \ldots 4
\end{gathered}
$$

At the end, I summarize results and close with final assessments of German digitalization position.

\section{Patenting of Digital Technologies at the European Patent Office}

For about one decade, a drastic patent growth of digital technology is observed, raising application numbers worldwide at large international patent offices in the USA, Japan, China, and the European Union to new levels (WIPO, 2019a). The surge in patenting was preceded by digital technologies publications expansion, accelerating in early 1990s, e.g., for artificial intelligence (AI) (WIPO, 2019b, pp. 38-55). A crucial factor for intensifications of digital technology patenting is the advent of Fourth Industrial Revolution (4IR) that challenged traditional business models and required "new" appropriation instruments of economic actors (EPO, 2017). Between 2010 and 2019, European Patent applications for digital technologies at the EPO increased steadily from 18,349 by $60.9 \%$ to 29,528 submissions, with a maximum growth of $13.8 \%$ in 2019 (see Fig. 1) (own calculations on basis of EPO, 2020b). The only small reduction of applications by $-2.8 \%$ was recorded in 2011 . In average, digital technology filings increased in the analyzed period by $5.5 \% \mathrm{p}$. a. The expansion was accompanied by a gain of digital technologies in overall patenting. Shares of digital technologies on entire EPO applications increased from $12.2 \%$ in 2010 to substantial $16.4 \%$ in 2019 . Digital technology weight on patent submissions enlarged steadily, with exception of 2018, an indicator of growing importance, with largest expansion by $9.3 \%$ in 2019 .

In especially large origination economies fostered the surge of digital technology patents at EPO in the last decade as Table 1 indicates (own calculations on basis of EPO, 2020b). US and Chinese applicants dominated in 2019 EPO's digital patent applications, covering $55.9 \%$ of top 10 economy submissions. US-originated applications were responsible for major share of $36.2 \%$ filed by top 10 countries. Chinese applicants, as second largest origination who started catching up about 10 years before, followed with increasing shares. With large lag to leading economies followed Japan, R. Korea, Germany, Sweden, and France, which revealed above 1,000 patent counts for digital technology each in 2019. At top 10 economies, low end ranged UK $(1,113 \%$ distance to top), Netherlands $(1,342 \%)$, and Finland $(1,869 \%)$ with huge distance to the leading USA. Also in the fifth rank, Germany still recorded $350.8 \%$ to top distance in digital technology patenting in 2019.

Picture changes completely if an economy size control in patenting is applied. Here, national weights of digital technologies on EPO patents are considered, measured by digital technology shares at aggregated national applications, as shown in Fig. 1 at right scale. China revealed with $42.8 \%$ EPO's largest digital patent 


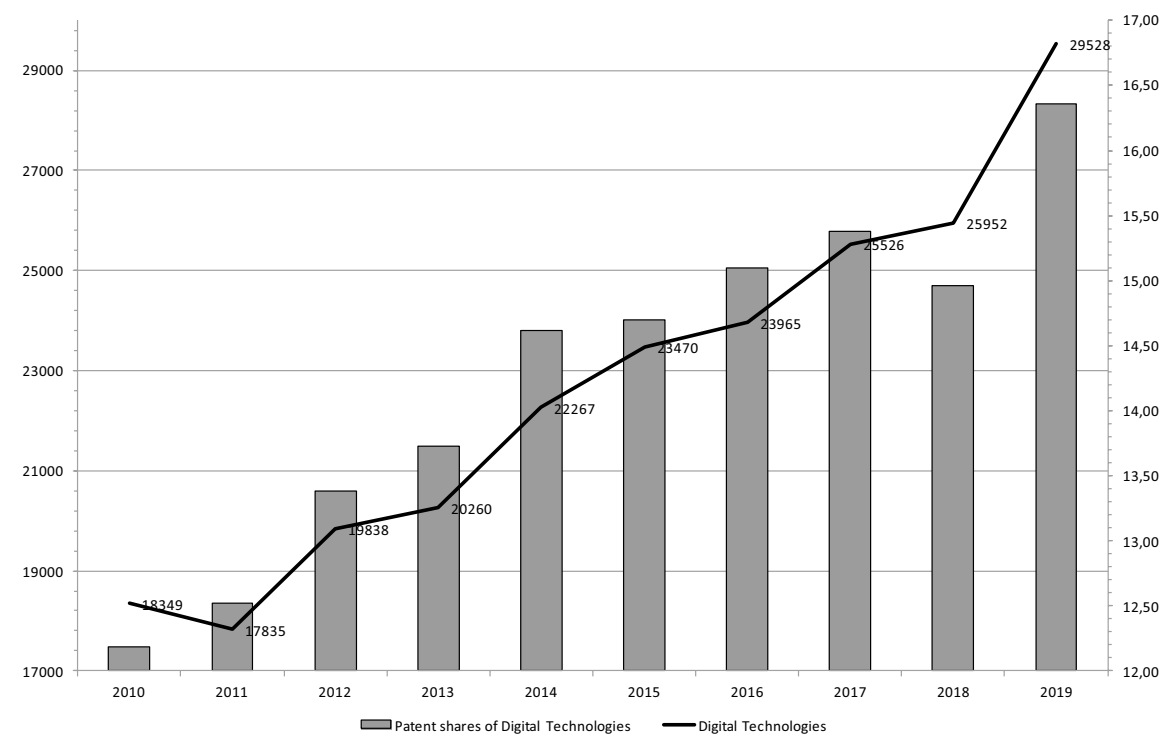

Source: own calculations and elaboration on basis of EPO (2020b).

Fig. 1 European Patent Applications 2010-2019 for digital technologies (patent counts left scale, patent shares on aggregated patent applications right scale). Source: own calculations and elaboration on basis of EPO (2020b)

proportion with huge lead (see Table 1) (own calculations and elaborations on basis of EPO, 2020b). The leading US economy, with respect to application counts,

Table 1 Top 10 economies of European Patent applications for digital technologies and national patent shares of digital technologies in 2019 (patent counts [numbers], digital technology shares on aggregated patent applications [\%])

\begin{tabular}{llllll}
\hline Rank & Economy & Patent counts & Rank & Economy & Patent shares \\
\hline 1 & USA & 9,550 & 1 & P.R. China & 42.77 \\
2 & P.R. China & 5,197 & 2 & Sweden & 36.15 \\
3 & Japan & 2,760 & 3 & Finland & 28.55 \\
4 & R. Korea & 2,158 & $(4)$ & Estonia & 26.53 \\
5 & Germany & 2,119 & 4 & R. Korea & 26.34 \\
6 & Sweden & 1,578 & 5 & Chinese Taipei & 23.05 \\
7 & France & 1,079 & 6 & USA & 20.74 \\
8 & UK & 787 & 7 & Ireland & 18.44 \\
9 & Netherlands & 662 & 8 & Canada & 17.58 \\
10 & Finland & 485 & $(9)$ & Cyprus & 15.22 \\
& & & 9 & Israel & 13.73 \\
& & & 10 & UK & 12.81 \\
\hline
\end{tabular}

Source: own calculations and depiction on basis of EPO (2020b) 
ranked with $20.7 \%$ at 6th place according digital shares. China's dominance in digital patenting becomes evident in direct comparison with Sweden and Finland (2nd and 3rd rank). They both recorded large distances of 18.3 and $49.8 \%$ of digital shares to the leading Chinese economy. Germany, with digital share of $7.9 \%$, was not capable to catch up with leading economies. In the top rank are also Estonia (4th) and Cyprus (9th place); however, both economies recorded very small patent filings in this field (13 and 7), indicating only minor contributions to digital technology patents at EPO. Hence, in analysis, they were considered as statistical outliers. On the contrary, for Ireland with multitude European headquarters of major digital tech companies, like Google, Facebook, Apple, or Microsoft, the quantitative impact on European patent filings is considerable (Shehadi, 2020). Favorable locational conditions of the Irish financial service center, connecting fintech and digital innovation, encouraged also many fintech enterprises, like TrueLayer, Coinbase, Stripe, Remitly, Square, Paysafe, or Payoneer, who made Ireland their "place of choice" in the European Union for business activities in Europe (Duncan, 2021). Also, UK's decision for BREXIT in 2016 altered the European digital tech landscape in the long run, favoring tech hubs with stable regulatory framework and innovation-friendly digital ecosystems (DuChene, 2019). Shares of digital technology at national patent outcomes can be interpreted not only as indicators of competitiveness in technology fields but also as signs for national technology specialization intensities. According to this, increasing digital technology shares of EPO filings reflect an increased specialization on digital technologies in patent filings since 2010 (see Fig. 1). But they indicate also in commercial perspective intensified efforts in business purpose applications of digital technology patents, e.g., in technology protection, bargaining, or venture capital financing. Furthermore, increasing national digital shares show domestic specialization pattern in digital technology. Chinese emergence in digital patenting outranged the competition field. However, also Sweden and, with lag, Finland, Estonia, R. Korea, and Chinese Taipei revealed signs for intensive industrial specializations in digital technology in 2019. In contrast, for Germany, no sign for digital specialization is visible.

\section{Current Development of Germany's European Patents of Digital Technology}

If digital technology patent filings of German-originated applicants at EPO in 2010-2019 are analyzed, we can derive differentiated insights (see Fig. 2) (own calculations and elaborations on basis of EPO, 2020b). Digital technologies cover technology fields of digital communication, computer technology, and IT methods for management. German applicants filed with lead major patent shares in computer technology. This contrasts main EPO applications trends, where digital communication received with 14,175 counts most filings. Computer technology ranked second at EPO (12,774 counts) and third, with huge lag, IT methods for management with 2,579 counts. German applicants mainly adhere to computer technology development. This is backed by long German engineering tradition, dating back among others to first freely programmable mechanical computer Z1, calculating on binary basis, built by Konrad Zuse in 1937 (Rojas, 1997). In contrast, major 


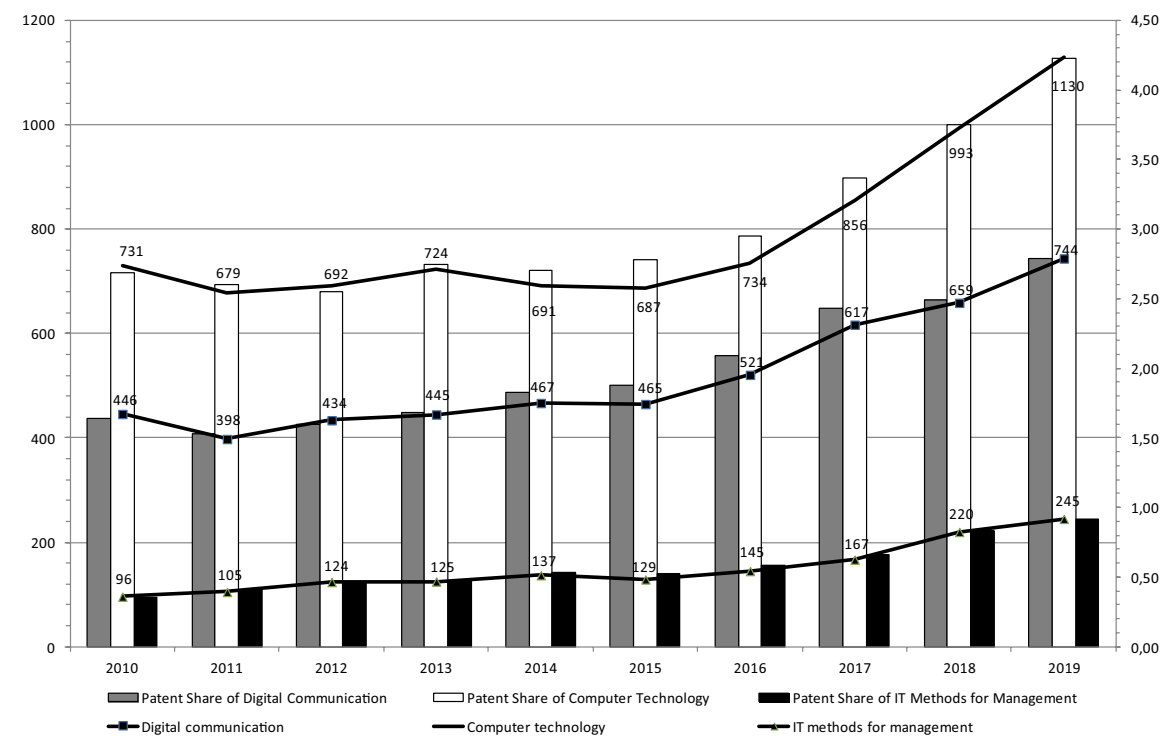

Source: own calculations and elaborations on basis of EPO (2020b).

Fig. 2 European Patent applications of Germany 2010-2019 for digital technologies (patent counts [numbers] left scale, patent shares on aggregated patent applications of Germany [\%] right scale). Source: own calculations and elaborations on basis of EPO (2020b)

international trends of fast digital communication expansion are underrepresented in German filings. The difference of computer technology patent counts and digital communication reduced from 2014 to 2017, but again increased later, driven by German computer technology filing dynamics. In contrast to larger fields, IT methods for management only covered small shares of Germany's contribution to digital technology progress. Nevertheless, IT method filings revealed an intact growth trend from 96 patents in 2010 to 245 applications in 2019. Their shares increased from 0.35 to $0.92 \%$, reflecting minor importance for German industry patents. In contrast, computer technology and digital communication applications recorded larger signs of specialization. Digital communication shares increased from 1.64 to $2.78 \%$, those of computer technology from 2.69 to $4.23 \%$. Interpreting German patent results, digital technology gained in all fields importance, however, based on small levels. Computer technology, the largest German field, even recorded stagnations from 2010 to 2015, with filings dropping below initial levels. But increased application dynamics expanded patent counts afterwards to 1,130 in 2019. Digital communication filings experienced also first stagnation, starting from small 446 applications, but recovered finally to 744 counts. In total, digital communication filings increased in the analyzed period by $66.8 \%$, computer technology by $54.6 \%$, both outpaced by IT methods for management with $155.2 \%$. In annual growth rates, digital communication expanded in average by $6.2 \%$, computer technology by $5.3 \%$, and IT methods for management by $11.4 \%$ with high volatilities $(6.3 \%$ points in average deviation from annual average in digital communication, $7.2 \%$ points in computer technology, $7.1 \%$ points in IT methods for management). In sum, most patents filed German applicants in computer 
technology, followed by digital communication and IT methods for management, with increasing tendency. On small levels, also signs for increasing specialization in digital technology fields were recorded.

\section{Germany's Position in European Digital Technology Patents in a European Perspective}

The picture varies if the German position in European digital patents at EPO with respect to top 5 economies is considered (USA, China, Japan, Korea, and Germany, see Table 1). Despite potential home biases in digital technology patents, the US economy leads the competition with huge lead, filing between 2010 and 2019 a dominant share of applications (see Fig. 3) (own calculations and elaborations on basis of EPO, 2020b). US applicants increased their patents from 6,247 filings in 2010 by $52.9 \%$ to 9,550 in 2019 with an average growth of $5.2 \%$ p.a. For digital technology, China's role is striking: filing in 2010, only 855 applications (5th rank), China reached in fast catching up just in 2011 German and Korean filing levels, in 2015 even Japanese. Since 2010, China expanded filings by $508.4 \%$ to 5,197 applications by $24.1 \%$ p. a. The German economy did not hold pace with Chinese dynamics in dig tech patents but rather developed analogue to Korean patent pattern. Filings increased from 1,273 by $66.4 \%$ to 2,119 in 2019 with an average growth of $6.1 \%$ p.a. As a result, Germany's application dynamics failed to cope up with China or USA. However, it kept close contact to Korean position and reduced the innovation gap to Japanese 3rd placed economy, which experienced application stagnation. Finally, German inventors ranked due to small patent dynamics on 5th place of EPOs top list. Also, patent structures of involved applicant's countries were rendered. All top

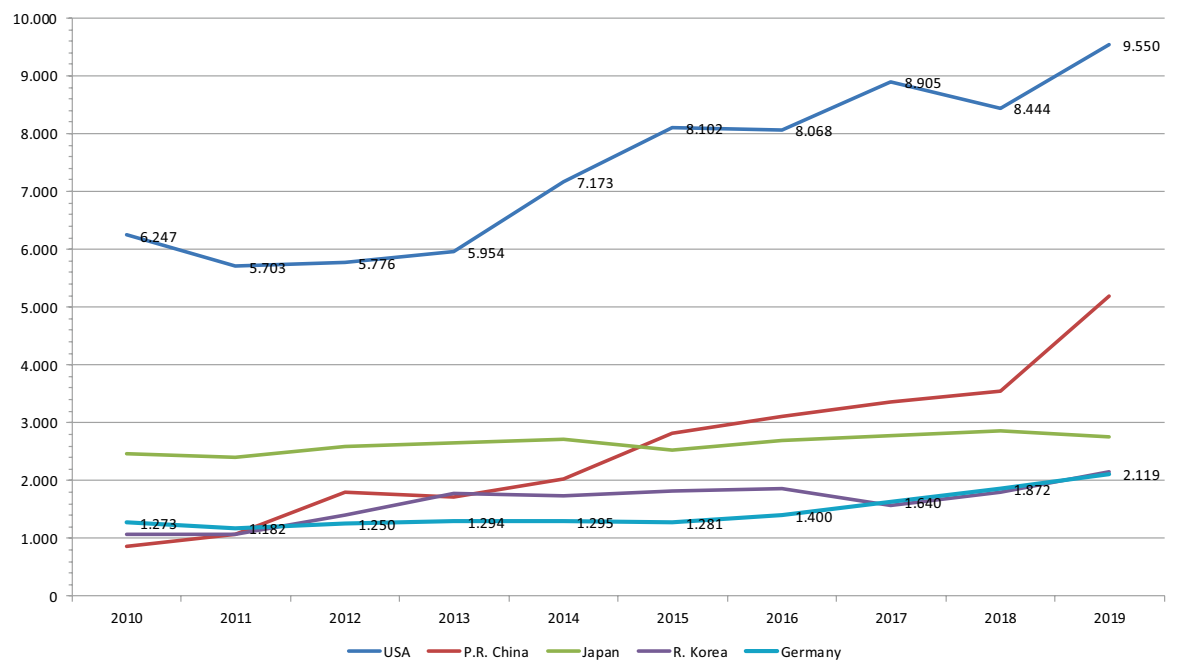

Fig. 3 Top 5 economies in European Patent applications 2010-2019 for digital technology (patent counts [numbers]). Source: own calculations and elaborations on basis of EPO (2020b) 
5 economies intensified specializations, however, to different degrees. USA, leading according to filing numbers, increased dig tech patent shares at aggregated patents from $15.8 \%$ in 2010 by 31.0 to $20.7 \%$ in 2019 , with peak of $21.0 \%$ in 2017. In terms of digital technology specialization, it remained in the 3rd rank. China even increased its dig tech share from extraordinary $40.1 \%$ in 2010 by 6.7 to $42.8 \%$ in 2019 with a $48.6 \%$ peak in 2015 and underlined its outstanding position. Korea, 2nd ranked origination country, increased specialization shares from $22.5 \%$ in 2010 by 17.3 to $26.4 \%$ in 2019 . Out of top 5, Germany recorded smallest digital technology shares, hinting on low specialization in digitalization, measured by patent protection. From 2010 to 2019, German inventors increased digital shares from $4.7 \%$ by 68.1 to $7.9 \%$. With these improvements, they still not coped up with next largest Japanese competitor but reduced dig tech specialization gaps. In sum, results show considerable Chinese catching up in digital technology patent counts to leading US but also stable national specialization patterns in the top group with leading Chinese origination. In contrast, German applicants increased patent filings at low pace, hence, losing past positions in international competition. An in-depth analysis of German applications shows the following results for fields of digital communication, computer technology, and IT methods for management at EPO.

\section{Germany's Position in European Digital Communication Patents in a European Perspective}

In 2019, Germany ranked in digital communication technology patenting (IPC H04L) (WIPO, 2022) in 6th place; hence, I analyze patent activities in comparison with top 5 group (China, USA, Sweden, Japan, and Korea). Until 2018, the USA dominated next ranked originations clearly (see Fig. 4) (own calculations and elaborations on basis of EPO, 2020b). US filings increased from 2,470 in 2010 by $49.2 \%$ to 3,684 applications in 2019 with an average of $5.2 \%$ p.a. Like in digital technology, China experienced dynamic catching up in digital communication, expanding filings from small 728 patents by $414.9 \%$ to 3,736 . Chinese inventors reduced the distance to the USA, surpassing it by 52 filings in 2019. The fast Chinese innovation dynamics in this field is indicated by extraordinary applications growth. Even the technology leader, USA, did not keep pace with Chinese growth of $22.8 \%$ p.a., ranking 2nd for first time in 2019. In the analyzed period, the German economy failed to close filing gaps to the top 5. German applications increased parallel to those of Japanese economy but on lower levels. Recorded distances even increased with respect to Sweden and R. Korea; hence, Germany departed from digital communication leaders of competition. Applications increased from 446 filings in 2010 by $66.8 \%$ to 744 in 2019 with an average growth of $6.2 \%$ p.a., too small to catch up in competition. To this also contributed stagnations until 2015 that could not compensated by later innovation dynamics increases. Empirical evidence shows risks of being passed through to worse digital communication positions in next future, if domestic efforts to R\&D investments are not increased. Same evaluation holds for small innovation dynamics in Japan. France, Finland, UK, and Netherlands as next ranked originations in 2019 preserved their large leads to Germany despite of dynamic competition of innovation 


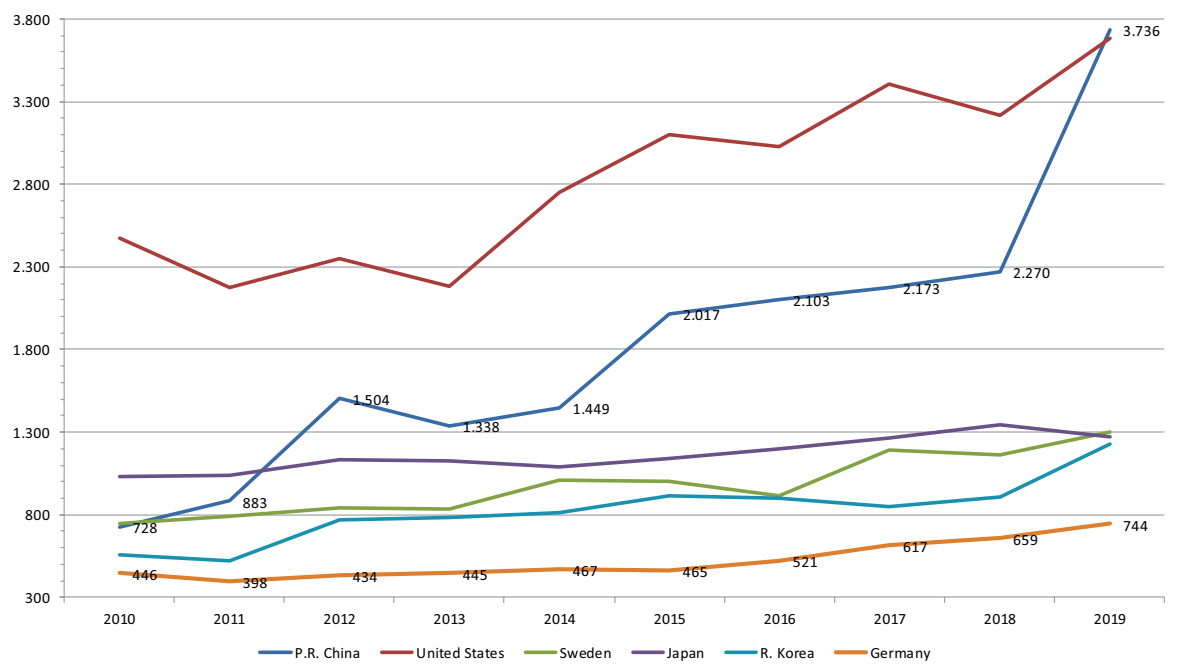

Fig. 4 Top 5 economies in European Patent applications 2010-2019 for digital communication versus Germany (patent counts [numbers]). Source: own calculations and elaborations on basis of EPO (2020b)

in digital communication that drives countries to intensify R\&D efforts just for holding positions. With respect to leading China and US dynamics, German innovation position weakens fast. The filings distance to China was $402.2 \%$, to the USA $395.2 \%$ in 2019 with increasing tendency. The German digital communication lag caused various factors. Major reason is an adherence to outdated ISDN-technologies (Integrated Services Digital Network) (Dinardi, 2022), later substituted by enhanced ISDN-DSL (Digital Subscriber Line) combinations in public communication networks. This reduced incentives for substitution by fiber optic technologies with comprehensive network coverage allowing for larger data speeds and bandwidths to run advanced applications, like Voice over IP-services (VoIP) (Moneycab, 2020) or multimedia applications. After ISDN network installation in 1995, Germany slowed down the fiber network rollout due to investment costs and still missing fast network applications. However, strong innovation activity requires various capacity input factors with technological infrastructure as precondition. Infrastructure deficits contributed to further impediments of German technological progress in digital communication. In contrast, specialization analysis reveals interesting insights in China's success explanation. Just in 2010, China's digital communication patent share was $34.1 \%$, however, still at small 728 filings. In the next decade, Chinese inventors preserved pattern of high specialization with a 30.8\% share in 2019 (maximum: 39.6\% 2012, minimum: $24.0 \%$ 2018). China's success in digital communication is a strategic R\&D policy result that relies on future technology outcomes. Even according digital communication shares second ranked Swedish origination didn't cope up with Chinese specializations long time. Still in 2010, Sweden recorded with its digital communication share of $20.9 \%$ a $13.3 \%$-point distance to leading China temporarily closing this gap and passing China with 31.4 and $28.9 \%$ in 2017/18. However, if filing counts are 
concerned, it plays only in second digital communication league. In 2010, Swedish applications exceeded with 748 counts than Chinese but later filing growth was not sufficient to compete with emerging Chinese performance. Applications increased by $6.9 \%$ p.a. to 1,301 filings (maximum: $29.7 \%$ in 2017) so patent growth exceeded USA (5.2\%) or Germany (6.2\%) but missed China's two-digit dynamics. In digital communication technology, US applicants play together with Chinese outstanding roles. In 2010-2019, US inventors increased applications from 2,470 by $49.2 \%$ to 3,684 , preserving to following Swedish origination a $64.7 \%$ distance. But, in contrast to China, the USA revealed only medium signs of digital communication specialization. Its patent specializations ranged between $6.2 \%$ in 2010 and $8.0 \%$ in 2019. Among the top countries, only Japan (5.8\%) and Germany (2.8\%) recorded smaller specializations in 2019. Hence, US digital communication innovations were not achieved on basis of specializations. German specializations expanded slightly at low levels from 1.6 to $2.8 \%$, indicating small innovation efforts in comparative perspective that resulted in large distances to leading economies (1,006\% to China, $972.3 \%$ to Sweden, and $440.0 \%$ to Korea). Potential catching ups require strong effort intensifications, leading to drastically increased digital communication shares. In sum, since 2010, German inventors failed in competition with leading economies and revealed minor signs of specializations in digital communication.

\section{Germany's Position in European Computer Technology Patents in a European Perspective}

At first glance, in computer technology (IPC G06\# not G06Q, G11C, G10L) (WIPO, 2022), the German innovation position is better than in digital communication. Patent filings were developed in close competition to other top 5 originations (USA, China, Japan, Germany, and Korea, see Fig. 5) (own calculations and elaborations on basis of EPO, 2020b). German inventors increased their applications from 731 in 2010 by $54.6 \%$ to 1,130 filings in 2019 with average growth of $5.3 \%$ p.a. Largest expansion was recorded with $16.6 \%$ in 2017 after previous stagnation. However, also remaining top 5 originations patenting characterized small growth, without China. Although US filings increased from 3,108 by $56.6 \%$ to 4,866 applications in 2019 , average growth was only $5.5 \%$ p.a. Korea ranked fifth and recorded $8.4 \%$ p.a., Japan even had minor decreases by $-1.1 \%$ p.a. As for digital communication, China revealed in computer technology extraordinary growth increasing filings from marginal 117 counts by $1,144.4 \%$ to 1,456 , fast lifting Chinese innovation position to second rank. In average rates, Chinese computer patents expanded by $32.4 \%$ p.a. with a $61.8 \%$ peak in 2012 . German activities recorded competitive position consolidations with respect to Korean filings, to Japan partial lag reductions. However, the surge of Chinese applications caused a German computer technology downgrading to 4th rank. Also if specialization intensity is considered, German inventors trailed in computer technology. Patent shares increased from 2.7 to $4.2 \%$; hence, growth was not sufficient to compete with other top 5 originations. They revealed larger computer technology shares that increased faster with exception of Korea and stagnating 


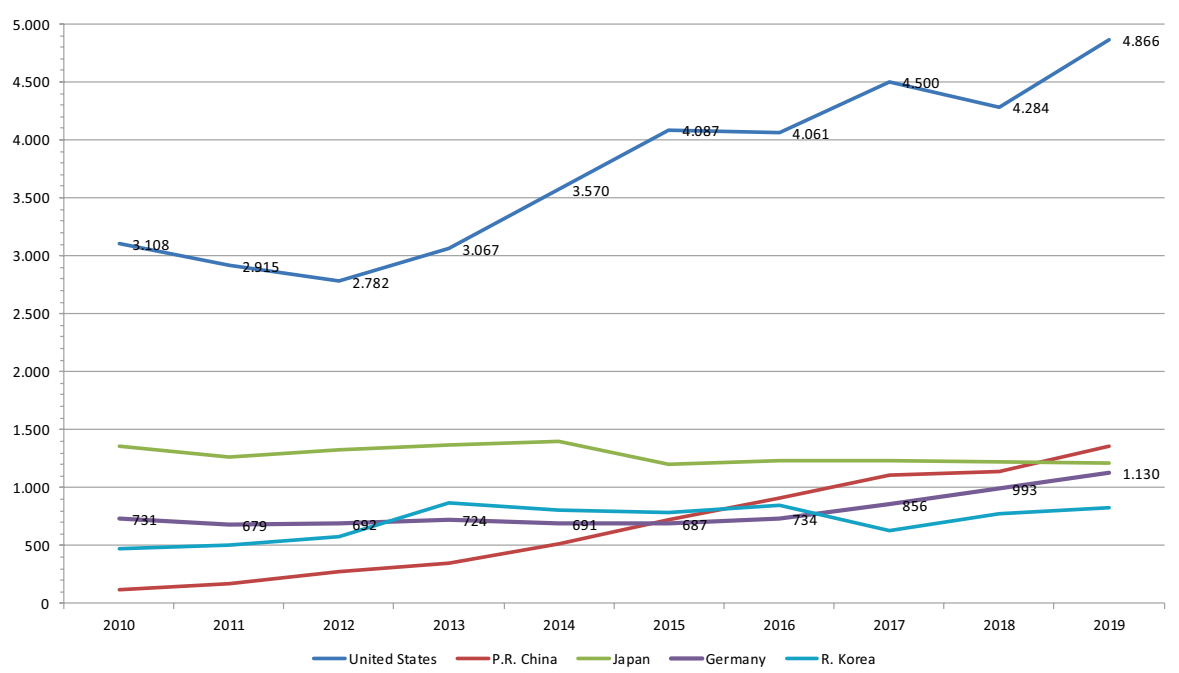

Fig. 5 Top 5 economies in European Patent applications 2010-2019 for computer technology (patent counts [numbers]). Source: own calculations and elaborations on basis of EPO (2020b)

Japan. US computer technology shares expanded from 7.9 to $10.6 \%$, Korean from 9.9 to $10.1 \%$, whereas China recorded increases from 5.48 to $11.2 \%$ holding since 2015 leadership of computer technology specialization. However, since 2016, Chinese specialization slightly reduced from $12.8 \%$; hence, innovation efforts indicate no further intensifications. Also for Japan and Korea, no signs of increased computer technology specializations are visible after peaks of $6.4 \%$ in 2014 and $13.8 \%$ in 2013. In sum, USA and China are most important computer technology benchmarks of Germany: the first origination with respect to patent application numbers and the second to fast growth dynamics. Both reveal strong specialization signs that foster innovation activities and are competition key factors.

\section{Germany's Position in European IT Methods for Management in a European Perspective}

IT methods for management (IPC G06Q) (WIPO, 2022) represent the smallest German digital technology field at EPO that holds also for other top 5 originations (USA, Japan, Germany, China, and Korea). IT methods for management overlap with business methods, which face considerable patenting restrictions by law and court ruling in EU and other countries (Mewburn Ellis, 2022). Together with strict EPO examinations (European Patent Office, 2022), European patent regulations potentially hamper filing expansion in this field. However, empirical analysis reveals considerable patent pattern diversity at European level. Like for computer technology, German innovation analysis provides ambivalent signs in IT methods (see Fig. 6) (own calculations and elaborations on basis of EPO, 2020b). German filings increased from 96 in 2010 by $155.2 \%$ to 245 in 2019 with an average of $11.4 \%$ 


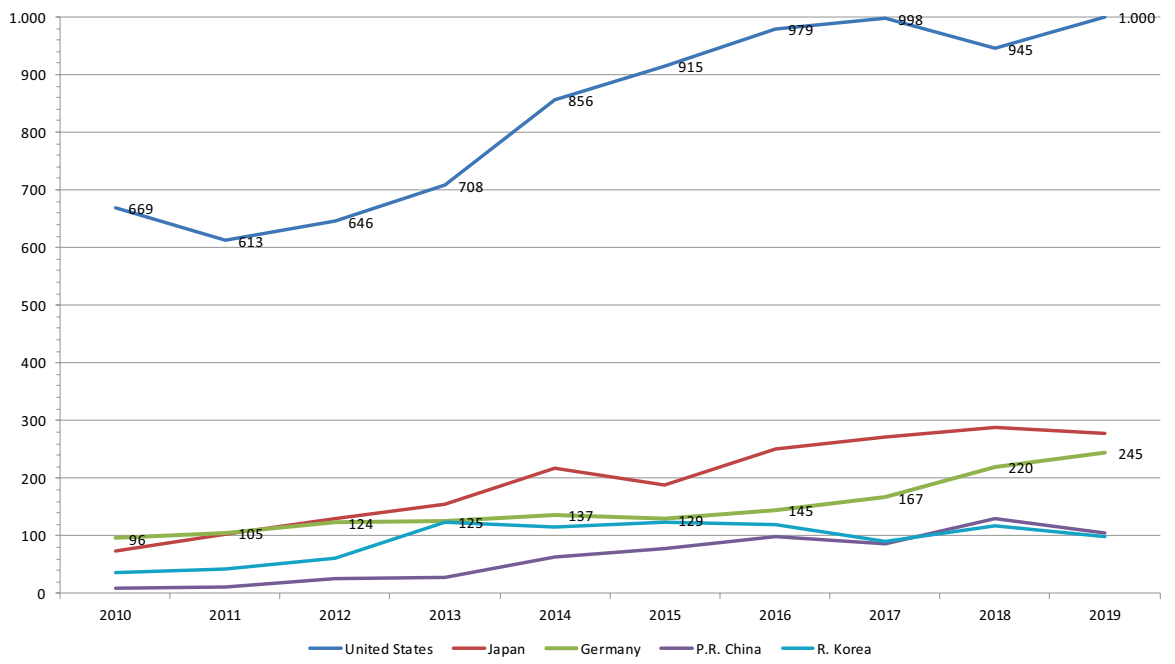

Fig. 6 Top 5 economies in European Patent applications 2010-2019 for IT methods for management (patent counts [numbers]). Source: own calculations and elaborations on basis of EPO (2020b)

p.a. German inventors defended patent positions against Chinese and Korean competitors but were outpaced by Japanese inventors, who increased filings from 73 by $280.8 \%$ to 278 in 2019 with an average of $17.5 \%$ p.a. Currently, German filing gaps to Japan were reduced partially. With exception of USA, which applications increased from 669 by $49.5 \%$ to 1,000 in 2019 with an average of $4.9 \%$ p.a., Germany revealed lowest growth out of top 5 economies. Large dynamics differences at the top become evident in comparison with fastest growing China (36.9\% p.a.). Despite large dynamics, however, China filed only 105 IT method patents in 2019. In application numbers, Germany faces close competition with Japan with a difference in filings of 33 patents in 2019 only. But the long-term German benchmark represents US filings in IT methods. A distance of 308.2\% in 2019 underlines outstanding US positions in this field. However, US innovation success is not based on IT methods for management specializations. In 2010, the USA revealed an IT method share of $1.7 \%$ and expanded it only marginally to $2.2 \%$ until 2019 . One supporting factor of US dominance is the innovation restraint of other originations in this field. Shares ranged from $0.9 \%$ in Germany and China to $1.3 \%$ in Japan in 2019 that indicated sluggish innovation activities. However, all top 5 economies showed signs for minor increases of specializations. Largest improvements recorded Japan from 0.3 to $1.3 \%$; next smaller shares revealed Korea with increases from 0.8 to $1.2 \%$, Germany from 0.4 to $0.9 \%$, and China from 0.5 to $0.9 \%$. Despite overall increasing shares, however, most economies departed from their peaks, e.g., Korea from $2.0 \%$ in 2013 , USA from $2.4 \%$, and China from $1.4 \%$ in 2016 ; hence, there is no clear specialization intensification trend. In sum, IT methods for management patents are dominated by the USA in filing numbers and China in growth dynamics. Small-growing German patent filings were outpaced by Japanese larger dynamics. 


\section{Does Specialization in Digital Technology Matters? A Measuring Approach}

At first glance, if above analysis results are considered, specializations dependencies of national successes in digital innovations could be assumed. Specializations are measured by technology field's patent shares on aggregated national patents. Synoptic results for Germany in 2019 are shown in Table 2 (own calculations and elaborations on basis of EPO, 2020b). From domestic perspective, larger specializations in specific technology fields are (qua definition) accompanied by larger patent activities with national patent outcomes given.

But do intensifications of specializations also beyond national levels support international success in digital innovation? Do larger digitalization specializations cause better international positions? In economic literature, several hypothesis support is found, arguing with positive specialization effects on general innovation activity (Ascania et al., 2020; Audretsch et al., 2011; Balland \& Boschma, 2019; Bierwald, 2014; Foray et al., 2018; Radosevic et al., 2017). To analyze this hypothesis empirically for EPO patents, the above-described dataset of 46 largest originations of filings in 2010-2019 is used, including a residual category for remaining filings, so entire originations amount to 47. Descriptive statistic results for the area of digital technologies (DT) with its field digital communication (DC), computer technologies CT, and IT methods for management ITM are shown in Table 3.

Empirical analysis results of estimations according the above-defined OLS model for each technology field are outlined in Table 4 (own calculations and elaborations on basis of EPO, 2020b). In the aggregated category of digital technology (see column (1) DT), the estimation of Eq. (5) reveals a positive medium influence of increased patent specializations on patent applications at a $99 \%$ level of significance, measured by the standardized regression coefficient beta of 0.381 . However, estimation's robustness is with a determination coefficient $R^{2}$ of only 0.145 small. Only $14.5 \%$ of patent application variance is explained by the regressor. We also find large residual standard deviations $s$ of 2.03693 . Hence, with $61.2 \%$ of dependent variable's mean value, the unexplained residual share is large and predictive estimation quality is restricted. The $F$-value is with 175.895 sufficiently large and highly significant ( $p$-value of 0.000). However, Durbin-Watson value $d$ is with 0.283 below lower critical value of positive autocorrelation test that indicates positive autocorrelation of

Table 2 Patent specialization and patent outcome of Germany in digital technology in 2019

\begin{tabular}{llll}
\hline Technology field & Technology subfield & $\begin{array}{l}\text { Share of technology field on } \\
\text { aggregated national patents [\%] }\end{array}$ & $\begin{array}{l}\text { Patent } \\
\text { filings } \\
\text { [numbers] }\end{array}$ \\
\hline Digital technology & & 7.93 & 2,119 \\
& Digital communication & 2.78 & 744 \\
& Computer technology & 4.23 & 1,130 \\
& IT methods for management & 0.92 & 245 \\
\hline
\end{tabular}

Source: Own calculations and elaborations on basis of EPO (2020b) 
Table 3 Descriptive statistics of patent specialization and patent outcome in European Patent applications for digital technology in 2010-2019

\begin{tabular}{lllrllr}
\hline $\begin{array}{l}\text { Technology } \\
\text { field/variable }\end{array}$ & $\boldsymbol{N}$ & Minimum & Maximum & Mean & Standard deviation & Variance \\
\hline DT & & & & & & \\
PS $^{\mathrm{DT}}$ & 1039 & .11 & 40.00 & 4.6586 & 5.46701 & 29.888 \\
$\operatorname{lnPA}^{\mathrm{DT}}$ & 1039 & .00 & 8.49 & 3.3299 & 2.20186 & 4.848 \\
$\mathbf{D C}$ & & & & & & \\
$\mathrm{PS}^{\mathrm{DC}}$ & 335 & .00 & 8.23 & 3.6790 & 2.38469 & 5.687 \\
$\operatorname{lnPA}{ }^{\mathrm{DC}}$ & 335 & .23 & 40.00 & 6.2140 & 7.69057 & 59.145 \\
$\mathbf{C T}$ & & & & & & \\
$\mathrm{PS}^{\mathrm{CT}}$ & 376 & .00 & 8.49 & 3.5867 & 2.28560 & 5.224 \\
$\operatorname{lnPA}{ }^{\mathrm{CT}}$ & 376 & .23 & 25.00 & 5.7291 & 3.97203 & 15.777 \\
$\mathbf{I T M}$ & & & & & & \\
$\mathrm{PS}^{\mathrm{I}}$ & 328 & .00 & 6.91 & 2.6790 & 1.72184 & 2.965 \\
$\operatorname{lnPA}$ & 328 & .11 & 14.29 & 1.8429 & 2.14987 & 4.622 \\
\hline
\end{tabular}

Source: Own calculations and elaborations on basis of EPO (2020b)

residuals at $95 \%$ significance in the estimation. In result, for digital technology, the zero hypothesis $\mathrm{H}_{0}$ can not be rejected and hypothesis $\mathrm{H}$ can not be confirmed. On basis of EPO data for 2010-2019, no significant impact of economy specializations on patent applications for this technology field is found in the estimation results. For digital communication, the estimation of Eq. (6) reveals comparable results, which are shown in column (2) DC of Table 4. Here contribute patent specializations with a standardized regression coefficient beta of 0.517 also with medium positive influences to patent applications but with a higher impact than found for digital technologies. The coefficient has a robust $99 \%$ level of significance but estimation's statistical quality is with a determination coefficient $R^{2}$ of 0.267 only low. The estimation explains only small shares of patent application variance with $26.7 \%$. Residual standard deviation $s$ reaches $2.0440655 .2 \%$ of dependent variable's mean value; hence, the unexplained residual share is large. The empirical $F$-value in the $F$-test ensures with 121.592 a regression coefficient different from zero with high significance at 99\% level. But, like for digital technologies, Durbin-Watson value $d$ indicates positive residuals autocorrelation at $95 \%$ significance. In result, also for digital communication, the zero hypothesis $\mathrm{H}_{0}$ can not be rejected; hence, no significant impact of specializations on patent applications is found in the estimation. Also for computer technology (see column (3) CT in table 4), estimation of Eq. (7) reveals comparable results. The highly significant standardized regression coefficient beta of 0.251 is smaller than for digital technologies and digital communication; the determination coefficient $R^{2}$ of 0.063 indicates increased shares of unexplained variance of patent applications and residual standard deviation $s$ of 2.21545 equals $61.8 \%$ of dependent variable's mean value. $F$-value is sufficiently large and at $99 \%$ significant, but DurbinWatson value $d$ of 0.242 indicates a positive residual autocorrelation. For computer technology, the zero hypothesis $\mathrm{H}_{0}$ can not be rejected. So test results show, based on 


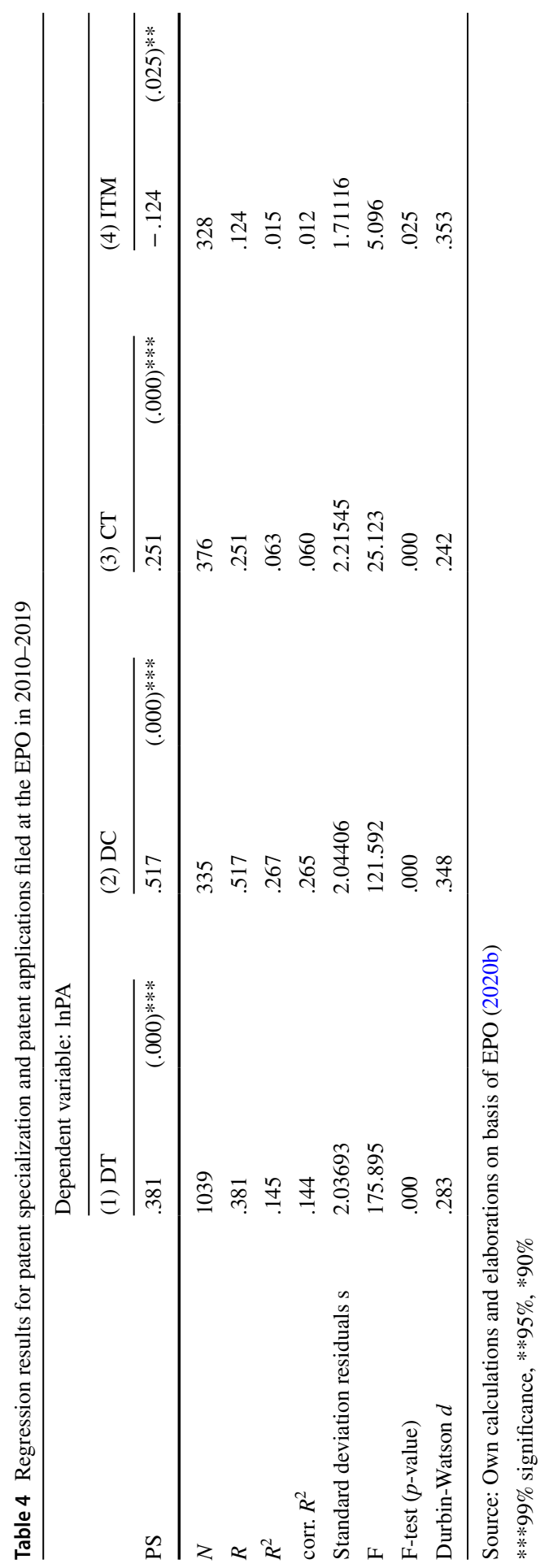


above estimation model, no significant impact of specializations on patent applications. For IT methods for management analysis, results are shown in column (4) ITM of Table 4 . The standardized regression coefficient beta reveals with -0.124 a negative sign with significance at $95 \%$ level, what contradicts assumptions of hypothesis H. In comparison with other technology field estimations, the determination coefficient $R^{2}$ is very small, residual standard deviation $s$ equals $63.9 \%$ of dependent variable's mean value. The empirical $F$-value is sufficiently large and significant at $95 \%$ but Durbin-Watson value $d$ of 0.353 indicates positive residual autocorrelation. In result, for IT methods for management, the zero hypothesis $\mathrm{H}_{0}$ can not be rejected and estimation shows also no significant impacts of specializations on patent applications.

\section{Specialization and Patenting in Digital Technologies: Discussion of Regression Results}

According to quantitative analysis results, no evidence for a statistically valid relation between specialization intensities and patent applications development of economies at the EPO in 2010-2019 is found for digital technology and its subcategories

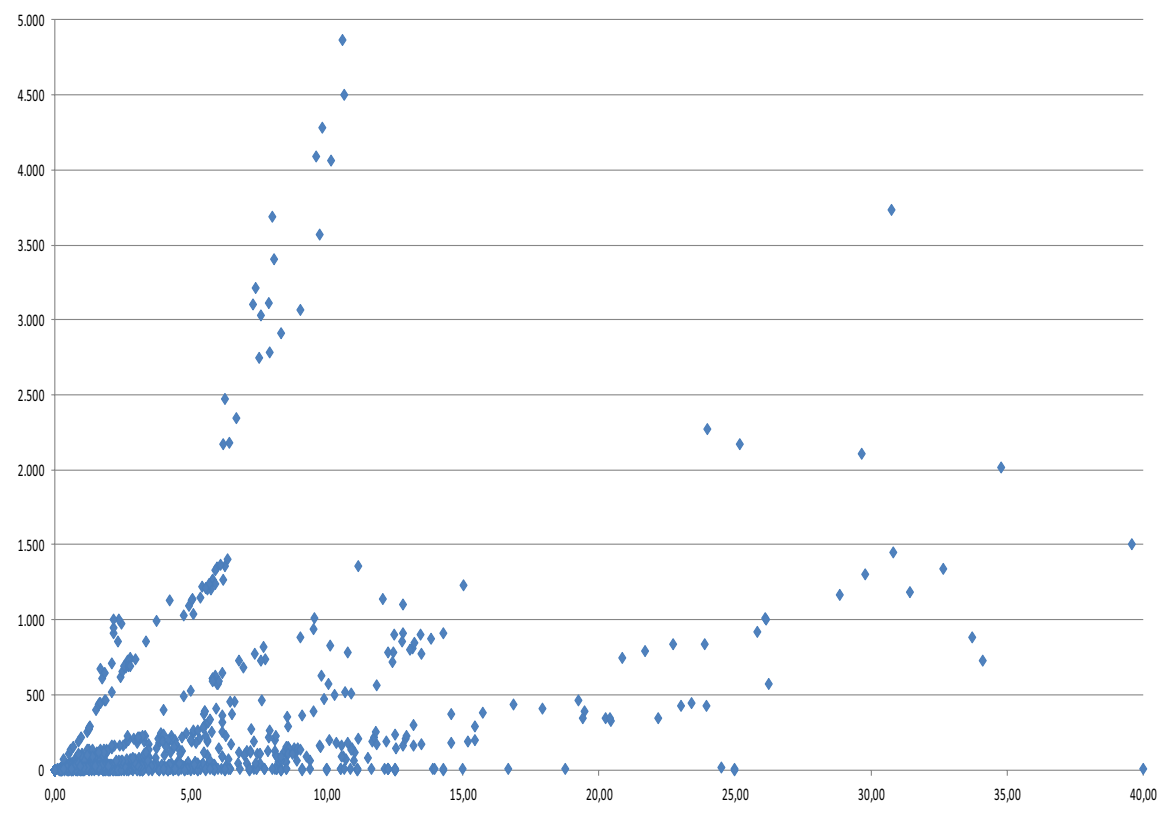

Source: own calculations and elaborations on basis of EPO (2020b).

Fig. 7 European Patent applications of all economies 2010-2019 for digital technology (plot patent shares, horizontal axis [\%], and patent applications, vertical axis [numbers]). Source: own calculations and elaborations on basis of EPO (2020b) 
digital communication, computer technology, and IT methods for management. If specialization matters for innovation activities with patent output, it is according to the analysis not visible in digital technology patent applications. Specialization as single factor seems not to matter in EPO digital technology patents, which are driven rather by a set of other economic determinants not included in the analysis, for instance, human capital, R\&D efforts, technological communities, innovation capabilities, and institutional framework (among others Teece, 2018 and Nelson, 2018). Further consideration of these factors is a shortcoming of the applied analysis. This contribution tried to answer the question if specializations in digital technology support innovation positions of economies at international level. The analysis results show no empirical evidence for this hypothesis. Specializations in digital technologies did not significantly contribute to improvements of international innovation positions in this field, measured by European patent filings in the analyzed period. Figure 7 illustrates the lacking significance of specialization intensities for EPO patent applications in digital technologies (own calculations and elaborations on basis of EPO, 2020b). For independent (specialization intensity) and dependent variables (patent filings), no sign for close relation is visible, hence, an indicator that the empirical influence hypothesis of specialization intensities on patent applications can not be confirmed by empirical tests of above model.

\section{Results and Final Remarks}

Digitalization processes are information economies' main drivers of innovation activities. Worldwide, instruments for digital technology development and utilization to foster innovation processes are applied by economic policy (Hanna, 2020). Increasing economic impacts of digitalization are reflected by the surge of digital technology patents. This paper analyzes German digitalization positions for patent filings at the European Patent Office between 2010 and 2019. The German economy belongs to the largest patent originations in digital communication, computer technology, and IT methods for management and revealed increasing filing outcomes. Most patents contained computer technology, followed by digital communication and IT methods for management. Furthermore, increasing digital technology importance for Germany signalizes specialization intensifications of all fields. However, Germany plays in international comparison only in the second innovation league, whereas USA and China dominate the innovation field. Increases of German digital technology filings and specializations are too small to compete with leading economies in future. German filings lag far behind USA and Chinese and Europe's largest economy reveals smallest specialization intensities out of five largest dig tech patent originations that restrict future innovation potentials. Best German results achieved filings in minor IT methods for management field, however, loosed ground against Japanese competitors. Patenting of German digital technologies reached in European perspective solid positions but innovation activities are not competitive with respect to international forefronts of technology development driven by USA and China. Emergence of China's digital technology success finds its explanation in early specializations indicated by large shares of dig tech at aggregated patents outcomes. Focusing digital patents for 
innovation, China applied at large scale an economic rationale of specializations also suggested by innovation economics. However, empirical analysis results of European patent applications for digital technologies in 2010-2019 show no significant relationship between patent specializations and patent filings. With the applied estimation model, no empirical evidence is found for positive specialization effects on European patent applications. Do digital technology specializations not matter? Are policy recommendations for digital technologies specializations obsolete due to lacking empirical evidence? At national level, like for China, increased digital technology specializations foster innovation and filing activities. For international competition, in line with innovation economics findings (Weresa, 2014), additional factors are regarded as joint innovation drivers, e.g., industrial structure, human capital, research and development efforts, and other innovation capacity factors. Moreover, beyond narrow technology focused Industry 4.0 concept, innovation economics literature hints on increasing importance of innovation framework deriving from knowledge society and public sphere (Quadruple Helix) and natural environments and ecosystems (Quintuple Helix) (Carayannis \& Campbell, 2021). Future research about joint factor impacts on digital technology patenting may reveal additional valuable insights. A second analysis shortcoming derives from European patent focus. Patent patterns at EPO level may diverge from filings at global national patent destinations, namely USPTO (U.S.), JPO (Japan), CNIPA (China), and with respect to Germany DPMA, or from international WIPO PCT-filings, due to home biases of applicants or European market specifics, like consumer preferences, product, and services requirements, income distributions, public regulations, or general patent policy. Third, global pandemic situation of SARS-CoV-2 virus since 2020 may foster digital technologies development, leading to structural changes in innovation patterns not covered by analysis. Digitalization processes are mirrored by expanding European patent applications for digital technologies as analysis results show. Dig tech filing activities reflect German strengths and weaknesses in specific technological fields thereby revealing valuable insights into developments of digital innovation.

\section{References}

Acatech. (2013). Securing the future of German Manufacturing Industry: Recommendations for implementing the strategic initiative INDUSTRY 4.0: Final report of the Industry 4.0 Working Group, National Academy of Science and Engineering. Forschungsunion, April, Frankfurt/Main, Retrieved January 25, 2022, from https://www.acatech.de/publikation/umsetzungsempfehlungen-fuer-daszukunftsprojekt-industrie-4-0-abschlussbericht-des-arbeitskreises-industrie-4-0/

Ascania, A., Bettarelli, L., Resminic, L., Balland, P. A. (2020). Global networks, local specialisation and regional patterns of innovation. Research Policy, 49 (8). https://doi.org/10.1016/j.respol.2020. 104031

Audretsch, D., Falck, O., Heblich, S. (2011). Who's got the aces up his sleeve? Functional specialization of cities and entrepreneurship. The Annals of Regional Science, 46, 621-636. https://doi.org/10. 1007/s00168-009-0353-0

Bacchiocchi, E., Montobbio, F. (2010). International knowledge diffusion and home-bias effect: Do USPTO and EPO patent citations tell the same story? The Scandinavian Journal of Economics, 112(3), 441-470. https://doi.org/10.1111/j.1467-9442.2010.01614.x 
Balland, P. A., Boschma, R. (2019). Smart specialization: Beyond patents: Project 2018CE160AT089/090: Final report. European Commission. Directorate-General for Regional and Urban Policy, Directorate Smart and Sustainable Growth and Program Implementation IV. Unit Smart and Sustainable Growth. Brussels. Retrieved January 25, 2022, from https://ec.europa.eu/regional_policy/en/information/publications/studies/ 2020/smart-specialisation-beyond-patents

Balsmeier, B., Woerter, M. (2019). Is this time different? How digitalization influences job creation and destruction, Research Policy, 48, October. https://doi.org/10.1016/j.respol.2019.03.010

Baruffaldi, S., Beuzekom, B. v., Dernis, H., Harhoff, D., Rao, N., Rosenfeld, D., Squicciarini, M. (2020). Identifying and measuring developments in artificial intelligence: Making the impossible possible. OECD Science, Technology and Industry Working Papers 2020/05. Retrieved January 25, 2022, from https://doi.org/10.1787/18151965

Beltagui, A., Rosli, A., Candi, M. (2020). Exaptation in a digital innovation ecosystem: The disruptive impacts of 3D printing. Research policy, 49(1), 103833. https://doi.org/10.1016/j.respol.2019. 103833

Bierwald, J. (2014). Specialization in online innovation communities: Understand and manage specialized members. Springer Gabler.

Bitkom. (2020). Deutsche Wirtschaft läuft der Digitalisierung weiter hinterher. Presseinformation. 20.01.2020, Bitkom, Retrieved January 25, 2022, from https://www.bitkom.org/Presse/Presseinformation/DeutscheWirtschaft-laeuft-der-Digitalisierung-weiter-hinterher

Brunswicker, S., Schecter, A. (2019). Coherence or flexibility? The paradox of change for developers' digital innovation trajectory on open platforms. Research Policy, 48(8), 103771. https://doi.org/10. 1016/j.respol.2019.03.016

Bundesregierung. (2020). Digitalisierung gestalten: Umsetzungsstrategie der Bundesregierung. 5. Aktualisierte Ausgabe. Berlin. Retrieved January 25, 2022, from https://www.digital-made-in.de/dmide

Carayannis, E. G., Campbell, D. F. J. (2021). Democracy of climate and climate for democracy: The evolution of quadruple and quintuple helix innovation systems. Journal of the Knowledge Economy, 12, 2050-2082. https://doi.org/10.1007/s13132-021-00778-x

Chabchoub, N., Niosi, J. (2005). Explaining the propensity to patent computer software. Technovation, 25, 971-978.

Cirillo, V., Evangelista, R., Guarascio, D., Sostero, M. (2020). Digitalization, routineness and employment: An exploration on Italian task- based data. Research Policy, Article in Press. https://doi.org/ 10.1016/j.respol.2020.104079

CNIPA. (2021). Public satisfaction over China's IP protection hits record-high in 2020. Beijing, Retrieved January 25, 2022, from https://english.cnipa.gov.cn/art/2021/5/12/art_2509_159306.html

Cohen, W.M., Nelson, R.R., Walsh, J.P. (2000). Protecting their intellectual assets. Appropriability conditions and why US manufacturing firms patent (or not). NBER Working Paper. no. 7552. Cambridge/Massachusetts. Retrieved January 25, 2022, from http://www.nber.org/papers/w7552.pdf

Comino, S., Manenti, F. M., Thumm, N. (2018). The role of patents in information and communication technologies: A survey of the literature. Journal of Economic Surveys, 33(2), 404-430.

Criscuolo, P. (2006). The 'home advantage' effect and patent families. A comparison of OECD triadic patents, the USPTO and the EPO. Scientometrics, 66(1), 23-41. https://doi.org/10.1007/s11192-006-0003-6

Dinardi, G. (2022). What is ISDN? Advantages, types, and who uses it. Nextiva blog. Retrieved January 25, 2022, from https://www.nextiva.com/blog/what-is-isdn.html?irpid=123201\&utm_source= affiliate\&utm_medium =ads\&utm_campaign=impactr\&utm_content $=104846 \&$ irclickid $=$ SM7Q $\%$ 3ARyhexyIRzmX30wL5WzCUkG3Eb1xF3vc3c0

Domini, G., Grazzi, M., Moschella, D., Treibich, T. (2020). Threats and opportunities in the digital era: Automation spikes and employment dynamics. Research Policy, Article in Press. https://doi. org/10.1016/j.respol.2020.104137

DPMA. (2021). Annual report 2020. German Patent and Trademark Office, Munich, Retrieved January 25, 2022, from https://www.dpma.de/digitaler_jahresbericht/2020/jb20_en/patents.html

DuChene, P. (2019). The tech scene in Dublin: what you need to know. TechRadar. News. Computing. 16.01.2019, Retrieved January 25, 2022, from https:/www.techradar.com/news/ the-tech-scene-in-dublin-what-you-need-to-know

Duncan, E (2021). TrueLayer chooses Dublin for European HQ. OpenBankingExpo. News. 26.08.2021, Retrieved January 25, 2022, from https://www.openbankingexpo.com/news/truelayer-choosesdublin-for-european-hq/ 
Eiteneyer, N., Bendig, D., Brettel, M. (2019). Social capital and the digital crowd: Involving backers to promote new product innovativeness. Research Policy, 48(8), 103744. https://doi.org/10. 1016/j.respol.2019.01.017

European Commission. (2020). Digital economy and society index (DESI) 2020: Germany. Brussels. Retrieved January 25, 2022, from https://ec.europa.eu/digital-single-market/en/news/digital-economyand-society-index-desi-2020

European Patent Office. (2017). Patents and the Fourth Industrial Revolution: The inventions behind digital transformation. Munich. Retrieved January 25, 2022, from http://documents.epo.org/projects/babylon/ eponet.nsf/0/17FDB5538E87B4B9C12581EF0045762F/\$FILE/fourth_industrial_revolution_2017 en.pdf

European Patent Office. (2020a). Digital technologies take top spot in European patent applications. News. $12^{\text {th }}$ march. Munich. Retrieved January 25, 2022, from https://www.epo.org/news-events/news/2020a/ 2020a0312.html

European Patent Office. (2020b). Patent Index 2019. Munich. Retrieved January 25, 2022, from https:// www.epo.org/about-us/annual-reports-statistics/statistics/2019_de.html

European Patent Office. (2022). Claims directed to computer-implemented inventions. Guidelines for Examination, Munich, Retrieved January 25, 2022, from https://www.epo.org/law-practice/legaltexts/html/guidelines/e/f_iv_3_9.htm

Foray, D., Morgan, K., Radosevic, S. (2018). The role of smart specialization in the EU research and innovation policy landscape. European Commission. Brussels. Retrieved January 25, 2022, from https:// ec.europa.eu/regional_policy/sources/docgener/brochure/smart/role_smartspecialisation_ri.pdf

Forman, C., Zeebroeck, N. v. (2019). Digital technology adoption and knowledge flows within firms: Can the Internet overcome geographic and technological distance? Research Policy, 48. https://doi. org/10.1016/j.respol.2018.10.021

Frietsch, R. et al. (2010). The value and indicator function of patents. Studien zum deutschen Innovationssystem. Nr. 15-2010, Fraunhofer Institute for Systems and Innovation Research, on behalf of Expertenkommission Forschung und Innovation (EFI), Berlin, Retrieved January 25, 2022, from https://www.isi.fraunhofer.de/content/dam/isi/dokumente/cci/efi-studien/2010/2010_StuDIS_15.pdf

Gabler Wirtschaftslexikon. (2022). Digitale Technologien, Springer Gabler, Retrieved January 25, 2022, from https://wirtschaftslexikon.gabler.de/definition/digitale-technologien-54127

Hanna, N.K. (2020). Assessing the digital economy: Aims, frameworks, pilots, results, and lessons. Journal of Innovation and Entrepreneurship, 9(16). https://doi.org/10.1186/s13731-020-00129-1

Helfat, C. E., Raubitschek, R. S. (2018). Dynamic and integrative capabilities for profiting from innovation in digital platform-based ecosystems. Research Policy, 47(8), 1391-1399. https://doi.org/10. 1016/j.respol.2018.01.019

Hoeren, T., Guadagno, F., Wunsch-Vincent, S. (2015). Breakthrough technologies: Semiconductor, innovation and intellectual property. Economic Research Working Paper, No. 27, November. WIPO. Geneva. Retrieved January 25, 2022, from https://www.wipo.int/edocs/pubdocs/en/wipo_pub_econstat_wp_27.pdf

Johnson, K. (2021). What is digital technology? 25 best examples. February 08, 2021, Honest Pros and Cons, Retrieved January 25, 2022, from https://honestproscons.com/what-is-digital-technology-25best-examples/

JPO. (2021). JPO Status report. Japan Patent Office, Tokyo, Retrieved January 25, 2022, from https://www. jpo.go.jp/e/resources/report/statusreport/2021/document/index/all.pdf

Kim, D., Lee, H., Kwak, J. (2017). Standards as a driving force that influences emerging technological trajectories in the converging world of the Internet and things: An investigation of the M2M/IoT patent network. Research Policy, 46(7), 1234-1254. https://doi.org/10.1016/j.respol.2017.05.008

Lobo, S., Whyte, J. (2017). Aligning and reconciling: Building project capabilities for digital delivery. Research Policy, 46(1), 93-107. https://doi.org/10.1016/j.respol.2016.10.005

Mewburn Ellis, L. L. P. (2015). Patentability of Software and Business Method Inventions in Europe. from https://www.mewburn.com/law-practice-library/patentability-of-business-method-and-softwareinventions-in-europe-2

Miric, M., Boudreau, K. J., Jeppesen, L. B. (2019). Protecting their digital assets: The use of formal \& informal appropriability strategies by App developers. Research Policy, 48(8), https://doi.org/10.1016/j. respol.2019.01.012

Moneycab. (2020). VoIP Telefonie erobert den Markt weiter: klassische Telefontechnik wird stückweise abgelöst. Retrieved January 25, 2022, from https://www.moneycab.com/it/voip-telefonie-erobert-denmarkt-weiter-klassische-telefontechnik-wird-stueckweise-abgeloest/ 
Nambisan, S., Wright, M., Feldman, M. (2019). The digital transformation of innovation and entrepreneurship: Progress, challenges and key themes. Research Policy, 48(8). https://doi.org/10.1016/j. respol.2019.03.018

Nelson, R. (2018). Observations and conjectures stimulated by David Teece's "Profiting from Innovation in the Digital Economy...". Research Policy, 47(8), https://doi.org/10.1016/j.respol.2017.11.012

OECD. (2018). Germany policy brief digitalisation. Leveraging the opportunities of digitalisation in Germany. Paris. Retrieved January 25, 2022, from https://www.oecd.org/germany/Germany-policybrief-digitalisation.pdf

Olsson, H., McQueen, D. H. (2000). Factors influencing patenting in small computer software producing companies. Technovation, 20, 563-576.

Pershina, R., Soppe, B., Thune, T. M. (2019). Bridging analog and digital expertise: Cross-domain collaboration and boundary-spanning tools in the creation of digital innovation. Research Policy, 48 (9). https://doi.org/10.1016/j.respol.2019.103819

Radosevic, S., Curaj, A., Gheorghiu, R., Andreescu, L., Wade, I. (2017). Advances in the theory and practice of smart specialization. Academic Press.

Rojas, R. (1997). Konrad Zuse's legacy: The architecture of the Z1 and Z3. IEEE Annals of the History of Computing, 19 (2), 5-16. Retrieved January 25, 2022, from http://ed-thelen.org/comp-hist/Zuse_ Z1_and_Z3.pdf

Schallmo, D.R.A., Williams, C.A. (2018). History of digital transformation. in: Digital Transformation Now! SpringerBriefs in Business. Springer. 3-8. https://doi.org/10.1007/978-3-319-72844-5_2

Schmoch, U. (2008). Concept of a technology classification for country comparisons: Final report to the World Intellectual Property Organization (WIPO). IPC/CE/41/5 Annex. Fraunhofer Institute for Systems and Innovation Research. Karlsruhe. Retrieved January 25, 2022, from https://www.wipo. int/edocs/mdocs/classifications/en/ipc_ce_41/ipc_ce_41_5-annex1.pdf

Scott, S. V., Reenen, J. V., Zachariadis, M. (2017). The long-term effect of digital innovation on bank performance: An empirical study of SWIFT adoption in financial services. Research Policy, 46(5), 984-1004. https://doi.org/10.1016/j.respol.2017.03.010

Shehadi, S. (2020). Dublin tops European HQ location rankings. fDi intelligence. April 16, 2020. Retrieved January 25, 2022, from https://www.fdiintelligence.com/article/78092

Teece, D. J. (2018). Profiting from innovation in the digital economy: Enabling technologies, standards, and licensing models in the wireless world. Research Policy, 47(8), 1367-1387. https://doi.org/10. 1016/j.respol.2017.01.015

The Economist. (2015). Germany's industry. Does Deutschland do digital? Europe's biggest economy is rightly worried that digitisation is a threat to its industrial leadership. The Economist, November $21^{\text {st }}$, Retrieved January 25, 2022, from https://www.economist.com/business/2015/11/21/does-deutschlanddo-digital

USPTO. (2020). Digital and new technology designs. United States Patent and Trademark Office, Alexandria/Virginia, Retrieved January 25, 2022, from https://www.uspto.gov/ip-policy/patent-policy/digitaland-new-technology-designs

Verstegen, L., Houkes, W., Reymen, I. (2019). Configuring collective digital-technology usage in dynamic and complex design practices. Research Policy, 48(8). https://doi.org/10.1016/j.respol.2018.10.020

Weber, G., Hedemann, G. A., Cohausz, H. B. (2007). Patentstrategien. Carl Heymanns Verlag.

Weresa, M. (2014). Innovation, human capital and trade competitiveness: How are they connected and why do they matter? Springer.

World Intellectual Property Organization. (2009). IPC and Technology Concordance Table. Special Union for the International Patent Classification (IPC). IPC/CE/41/5. Geneva. Retrieved January 25, 2022, from https://www.wipo.int/edocs/mdocs/classifications/en/ipc_ce_41/ipc_ce_41_5-main1.pdf

World Intellectual Property Organization. (2019a). World Intellectual Property Indicators 2019. Geneva. Retrieved January 25, 2022, from https://www.wipo.int/edocs/pubdocs/en/wipo_pub_941_2019.pdf

World Intellectual Property Organization. (2019b). Artificial intelligence. WIPO Technology Trends 2019. Geneva. Retrieved January 25, 2022, from https://www.wipo.int/edocs/pubdocs/en/wipo_pub_1055.pdf

World Intellectual Property Organization. (2019c). IPC8 -technology concordance. Update July 2019c. Geneva. Retrieved January 25, 2022, from https://www.wipo.int/export/sites/www/ipstats/en/statistics/ patents/xls/ipc_technology.xls

World Intellectual Property Organization. (2022). International Patent Classification (IPC). Geneva. Retrieved January 25, 2022, from https://www.wipo.int/classifications/ipc/en/ 
World Economic Forum. (2018). Digital transformation initiative: Unlocking \$100 trillion for business and society from digital transformation. Executive Summary. May 2018. Cologny/Geneva. Retrieved January 25, 2022, from http://reports.weforum.org/digital-transformation/

Zehtabchi, M. (2019). Measuring innovation in the autonomous vehicle technology. Economic Research Working Paper No. 60. November. WIPO. Geneva. Retrieved January 25, 2022, from https://www. wipo.int/edocs/pubdocs/en/wipo_pub_econstat_wp_60.pdf

Publisher's Note Springer Nature remains neutral with regard to jurisdictional claims in published maps and institutional affiliations. 